\title{
PCB contamination in indoor buildings
}

\author{
S. J. Hellman ${ }^{1}$, O. Lindroos ${ }^{1}$, T. Palukka ${ }^{1}$, E. Priha ${ }^{2}$, T. Rantio ${ }^{2}$ \\ \& T. Tuhkanen ${ }^{1}$ \\ ${ }^{I}$ Tampere University of Technology, \\ Institute of Environmental Engineering and Biotechnology, Finland \\ ${ }^{2}$ Finnish Institute of Occupational Health, Finland
}

\begin{abstract}
PCBs can still be found in open applications such as additives in paints or elastic sealants used in buildings built in the 1960s and 1970s. The objectives of this study were to analyze the occurrence of PCBs in paints used in buildings. PCBs were applied especially in chlorinated rubber paints, cyclorubber paints and in vinyl paints, which have been used widely, especially in industrial buildings. The results from the research show that $60 \%$ of buildings studied contain PCB over $20 \mathrm{mg} / \mathrm{kg}$ in indoor paints. From all the samples collected almost every fourth contained PCBs over the limit value of $50 \mathrm{mg} / \mathrm{kg}$ given for hazardous waste. The highest concentration $(102900 \mathrm{mg} / \mathrm{kg})$ was found in the concrete floor of a school building's basement. Wipe samples taken from paint surfaces also contained high amounts of PCBs. The highest amount $\left(83000 \mu \mathrm{g} \mathrm{PCB} / \mathrm{m}^{2}\right)$ was found in the surface of a building, which had not yet been renovated. The most common method for removing existing paint is sandblasting. After sandblasting the sand contains high concentrations of PCBs and has a large surface area thus PCBs leaching capacity may be significant. This may cause occupational and also residential exposure to PCBs. In buildings that had been renovated by using sandblasting for paint removal, PCBs were found in the surface, which had not originally contained PCBs. The secondary contamination was often over the Finnish limit value of $100 \mu \mathrm{g} \mathrm{PCB} / \mathrm{m}^{2}$ as the highest concentration detected was $1100 \mu \mathrm{g} \mathrm{PCB} / \mathrm{m}^{2}$. The congener profiles from the samples reminded the profile of Aroclor 1260 or Clophen 60 profiles in almost all samples. The profiles showed that the PCBs most probably originate from paints and not from other PCB source such as capacitors.
\end{abstract}

Keywords: polychlorinated biphenyls (PCB), paint, indoor dust. 


\section{Introduction}

Polychlorinated biphenyls (PCBs) are a class of Persistent Organic Pollutants (POPs) that are highly toxic, resistant to degradation and have a high bioaccumulation potential. PCBs are transported through air, water and migratory species across international boundaries and deposited far from their place of release, where they accumulate in terrestrial and aquatic ecosystems (Gjessing et al [1]). The commercial production of technical mixtures of PCBs with different degrees of chlorination started in 1929. PCBs were soon used for various purposes; in closed systems in industrial applications such as heat exchange fluids in electrical transformers and capacitors (liquid PCBs) but also in various open applications such as softeners or additives in paints, sealants and varnishes (non-liquid PCBs). NLPCBs in buildings pose a possible risk from a residential, occupational and also an environmental point of view. The amount of PCBs produced worldwide from $1929-1977$ is estimated to be about 1.5 million metric tons (Breivik et al [2]). The serious risks associated with PCBs were noticed more than 30 years ago when Sören Jensen detected PCBs in pike from Sweden (Jensen [3]). Since then their use began to be restricted but PCBs are still found in use in previous applications.

In Finland PCBs can be found in buildings constructed from 1956-1975. PCBs are also found in soil in the vicinity of buildings (Hellman [4]). The use of PCBs in new building materials was banned in 1989 (VNp, 1071/1989 [5]). Even though the production of PCBs was stopped 30 years ago, PCBs continue to be detected in environmental samples and in the built environment around the world. Estimates of the volume of PCBs in sealants in Finland vary from 130 to $270 \mathrm{t}$ (Pentti and Haukijärvi [6]). The amount of PCBs used in paints and varnishes is approximately six times the amount of PCBs used in sealants (PCBcommittee report [7]).

In this study PCB containing materials investigated were paints in various applications. Also paint dust caused by aging of paints or sandblasting was examined. The objective was to find out to what extent PCBs exist in buildings built before the year 1975. The painted surfaces such as floors, walls and staircases were studied to find out where PCB containing paints were applied. The indoor air of industrial buildings as well as school buildings was sampled in order to find out about the presence of PCBs in the indoor air in different types of buildings.

The study adds up to the studies conducted earlier in Finland about PCBs in buildings $[4,8-10]$.

\section{Materials and methods}

\subsection{Sampling targets}

Samples were collected in different types of industrial and official buildings primarily according to their year of construction. Buildings were mostly located in the Tampere region and were built before the year of 1970. Some targets were 
undergoing renovations as they were constructed for residential use, for day-care centers or for offices. Firstly the industrial buildings and warehouses were studied. After that the sampling was extended as schools and military buildings were studied. Most of the paint and surface samples were taken from concrete floors but some were also taken from doors, doorsteps and walls.

All together 114 material samples were collected from 23 different buildings ( 8 schools, 7 old industrial buildings, 8 buildings used for military purposes). 21 surface wipe samples were taken from four different industrial buildings. Indoor air was sampled in ten targets, where 18 volatile samples and 14 particle-bound samples were taken. Also the penetration of PCBs from paint into the concrete underneath was studied by three drilling samples.

\subsection{Sampling methods}

The material samples of paints were taken by using metallic knife, scraper of chisel. The tools were cleaned after each sample with ethanol. The samples were packed in capped brown glass bottles and taken to the laboratory at the Tampere University of Technology (TTY). For wipe samples $1 \mathrm{~m} \times 1 \mathrm{~m}$ areas were marked as sampling locations. Two $20 \mathrm{~cm}$ x $20 \mathrm{~cm}$ areas were measured inside the marked sampling area. Clean cotton tissue was moisturized with $10 \mathrm{ml}$ of ethanol and each area was wiped twice with the same cotton. Cotton was then sealed in a glass tube and taken to the Institute of Occupational Health in Tampere (FIOH) for analysis. The air samples were collected with OVS tubes containing XAD-2 sorbent and a glass fiber filter. Suction velocity in pumps was about $211 \mathrm{~min}^{-1}$. Sampling time was about 2 hours. For drilling samples three holes were drilled to the surface, which was known to have PCB concentration of $23000 \mathrm{mg} / \mathrm{kg}$. Before drilling the paint was removed carefully. Upper depths were from surface to $2.5 \mathrm{~mm}, 3.5 \mathrm{~mm}$ and $5 \mathrm{~mm}$. The deeper wholes were drilled further up to $4,5 \mathrm{~mm}, 6 \mathrm{~mm}$ and $7.5 \mathrm{~mm}$ respectively.

\subsection{PCB-analyses}

Paint samples were extracted with hexane in an ultrasonic bath using 2,4,6trichlorobiphenyl (PCB 30) as an internal standard. For wipe samples $2,2^{\prime}, 3,3^{\prime}, 4,4^{\prime}, 5,5^{\prime}, 6,6^{\prime}$-decachlorobiphenyl (PCB209) was also added as an internal standard. The extracts from paint and wipe samples were cleaned up with concentrated sulphuric acid as needed. PCBs were determined by using Agilent Technologies gas chromatograph (6890) with an electron capture detector or mass selective detector (5971A or 5973). HP-5MS capillary column (30m long, $250 \mu \mathrm{m}$ internal diameter and $0.25 \mu \mathrm{m}$ of $1 \mu \mathrm{m}$ film thickness) was used with helium as a carrier gas (1 ml/min for MSD, $2 \mathrm{ml} / \mathrm{min}$ for ECD). Oven temperature at TTY started at the temperature $80^{\circ} \mathrm{C}$, was held for 1 minute and then increased to $150^{\circ} \mathrm{C}$ at $30{ }^{\circ} \mathrm{C} / \mathrm{min}$, to $250^{\circ}$ at $5^{\circ} \mathrm{C} / \mathrm{min}$ and to $300^{\circ} \mathrm{C}$ at $30^{\circ} \mathrm{C} / \mathrm{min}$. In $\mathrm{IHO}$ starting temperature was $70^{\circ} \mathrm{C}$, held for 1 minute and then increased to $250^{\circ}$ at $15^{\circ} \mathrm{C} / \mathrm{min}$ where hold for 20 minutes. The total $\mathrm{PCB}$ concentration in paint and wipe samples was calculated according to the PCB profile found in a sample. Sample profiles were compared to the profiles of 
technical mixtures Aroclor 1254 or Aroclor 1260. The individual PCB congeners used for quantification were 28, 31, 52, 77, 101, 105, 118, 126, 128, 138, 153, $156,169,179$ and 180 as their concentrations were determined. For air analysis both volatile and particulate PCBs were measured. Volatile gaseous phase PCBs were collected by using XAD-2 sorbent equipped with a Reciprotor-pump. The suction velocity was between $3-51 / \mathrm{min}$ and sampling time was 24 hours. Particulate phase PCBs were collected by using high-volume dust collector with a glass fiber filter (e.g. Staplex TFAGF41, diameter 10,16cm), suction velocity was about $0.7 \mathrm{~m}^{3} / \mathrm{min}$ and sampling time about an hour. XAD-2 sorbent and glass fiber filters were analyzed together. The total PCB concentration in air samples was calculated by using the method presented by Benthe et al [11]. The method adds up the concentrations of PCB congeners 28, 52, 101 and 138 and multiplies the sum with six. To assure the quality during the analysis, internal standards in samples, blank samples and calibration mixtures together with blank samples were used.

\section{Results}

\subsection{PCBs in paints}

Target buildings were chosen according to the year of construction or known reconstruction time so that the buildings were painted 1940-1972. The paint samples were collected from 8 schools (45 samples), 7 buildings known for previous industrial use (49 samples) and two military areas (20 samples). From 18 locations sampled, 11 sampling sites were found to contain PCBs over 20 $\mathrm{mg} / \mathrm{kg}$. From 114 samples $33 \mathrm{had}$ PCB-concentrations over $20 \mathrm{mg} / \mathrm{kg}$. The percentages of paint samples containing PCBs more than $20 \mathrm{mg} / \mathrm{kg}$ are summarized in table 1 . The highest concentration $(102900 \mathrm{mg} / \mathrm{kg})$ was analyzed at a schools boiler room where the sample was taken from the painted concrete floor. Over $10 \%$ of the dry weight of the paint was shown to consist of PCBs. Although, this was not the case in most of the samples the concentrations were still close to the regulatory limit value of $50 \mathrm{mg} / \mathrm{kg}$ for hazardous waste. The limit value was exceeded in 23 samples. Most of the samples that had high PCB concentrations were painted during 1950s.

Table 1: Percentage of paint samples containing more than $20 \mathrm{mg} / \mathrm{kg}$ of $\mathrm{PCB}$ in different building types.

\begin{tabular}{c|c}
\hline Building type & $\%$ \\
\hline School & 31 \\
Industrial & 24 \\
Military & 35 \\
\hline Total & 29 \\
\hline
\end{tabular}


Most of the high concentrations were on concrete basement floors in elementary school buildings. The congener profiles resembled mostly of the profile of Aroclor 1260 or Clophen 60. Aroclor 1254 was found in few paint samples.

\subsection{PCBs in surfaces}

Wipe samples were taken from painted surfaces known to contain PCBs. Seven targets were sampled and five of them exceeded the guideline limit of 100 $\mu \mathrm{g} / \mathrm{m}^{2}$, which is given for the control of occupational exposure surfaces in Finland (PCB-committee report, 1983). The highest surface concentration analyzed with known paint concentration was $75000 \mu \mathrm{g} / \mathrm{m}^{2}$. It was the spot that had the highest paint concentration $102900 \mathrm{mg} / \mathrm{kg}$ as well so it indicates that PCB concentrations in dust correlate with PCB concentrations in paint. Results are shown in table 2 .

Table 2: $\quad$ PCB-concentrations in surfaces vs. PCBs in paints.

\begin{tabular}{|c|c|}
\hline $\begin{array}{c}\text { PCB-concentration in } \\
\text { surface }\left(\boldsymbol{\mu g} / \mathbf{m}^{\mathbf{2}}\right)\end{array}$ & $\begin{array}{c}\text { PCB-concentration in } \\
\text { paint }(\mathbf{m g} / \mathbf{k g})\end{array}$ \\
\hline 120 & 70 \\
\hline 68 & 70 \\
\hline 44 & 530 \\
\hline 92 & 530 \\
\hline 2600 & 48000 \\
\hline 2100 & 23600 \\
\hline 25000 & 29000 \\
\hline 660 & 11000 \\
\hline$<8$ & $<20$ \\
\hline 230 & 280 \\
\hline 59000 & 69300 \\
\hline 10000 & 69300 \\
\hline $\mathbf{7 5 0 0 0}$ & $\mathbf{1 0 2} \mathbf{9 0 0}$ \\
\hline 5900 & 69300 \\
\hline 380 & 400 \\
\hline 2000 & 1990 \\
\hline 4100 & 1990 \\
\hline
\end{tabular}

Samples taken from the vicinity of PCB-containing paint showed secondary contamination, which is remarkable since the cleaning may not be done properly after renovations, if the presence of PCBs is unknown. 


\subsection{PCBs in air samples}

Ten targets were sampled; 18 air samples for volatile PCBs and 14 particle phase air samples for particulate PCBs. From 18 samples in six volatile PCBs were found to exceed the detection limit. The concentrations of particulate PCBs were detected in three samples out of 14. Summary of the samples is shown in table 3.

Table 3: Volatile (left) and particulate (right) $\mathrm{PCBs}$ in the indoor air samples.

\begin{tabular}{|c|c|c|c|}
\hline $\begin{array}{c}\text { Air } \\
\text { volume } \\
\left(\mathrm{m}^{3}\right)\end{array}$ & $\begin{array}{c}\boldsymbol{P C B} \\
\left(n g / m^{3}\right)\end{array}$ & $\begin{array}{c}\text { Air } \\
\text { volume } \\
\left(\mathrm{m}^{3}\right)\end{array}$ & $\begin{array}{c}\text { PCB } \\
\left(\mathrm{ng} / \mathrm{m}^{3}\right)\end{array}$ \\
\hline 4,5852 & $<50$ & 58,50 & $<4$ \\
\hline 4,6100 & $<50$ & 50,03 & $<5$ \\
\hline 4,5319 & $<50$ & 45,68 & $<5$ \\
\hline 6,1280 & 38 & 45,75 & $<5$ \\
\hline 6,1820 & 33 & 46,40 & $<5$ \\
\hline 0,6955 & $<100$ & 36,00 & $<7$ \\
\hline 1,0993 & $<60$ & 48,68 & $<5$ \\
\hline 4,7580 & 56 & 38,75 & 18 \\
\hline 4,7920 & 39 & 34,80 & 5,5 \\
\hline 5,6308 & 350 & 60,18 & $<4$ \\
\hline 4,1122 & 330 & 41,85 & $<6$ \\
\hline 6,2097 & $<40$ & 45,68 & $<5$ \\
\hline 5,1665 & $<50$ & 45,00 & 5,3 \\
\hline 2,8819 & $<80$ & 39,00 & $<6$ \\
\hline 2,6197 & $<90$ & 41,85 & $<6$ \\
\hline 0,5270 & 290 & & \\
\hline 5,8950 & $<40$ & & \\
\hline 0,7547 & 320 & & \\
\hline 0,5270 & 290 & & \\
\hline 5,8950 & $<40$ & & \\
\hline
\end{tabular}

\subsection{PCBs in concrete}

The penetration of PCBs from paint into the concrete underneath was studied by drilling samples from concrete surfaces. It was shown that PCBs penetrate into concrete in concentrations that are significant if thinking about the reuse of concrete.

\section{Discussion}

This study shows that PCBs have been added to various paints, which have been applied in various types of Finnish buildings, mostly indoors. The concentrations in paints exceed often the hazardous waste limit value of $50 \mathrm{mg} / \mathrm{kg}$. In Finland 
there is no legislation that especially requires testing old paints before renovation or demolition of buildings. Though, it is said that the construction company need to be aware of the safety requirements during construction work. If paints containing PCBs are removed by using sandblasting, it is evident that without sufficient knowledge there may be health risks associated with e.g. poor safety gear and the technique used. Also the question about demolition waste becomes important. This study suggests that demolition waste from buildings built and painted especially in late 1950s may contain significant amounts of PCB. If present, PCB concentrations in paints most probably will exceed the given limit value for hazardous waste and should be treated as hazardous waste.

There was no clear trend between the PCB concentrations in paints and the wipe sample concentrations in surfaces. An interesting thing was shown in a school building, as the surface concentrations were order of magnitude lower compared to the concentrations of other surfaces versus paint. The samples were taken from the floor, which was painted in 1951. Also another target showed the same trend as the painting year was 1954. This suggests that PCBs had been eroded away from the floor paint. This may be due to the cracking and erosion of an old paint.

Another question is the concrete under the painted surface. The limited investigations in this study suggest that $\mathrm{PCBs}$ pass the paint surface and are found also in underlying concrete. The results suggest that this should be further examined when testing concrete from demolished buildings for reuse purposes.

As the results show more attention should be paid on paint removal techniques as well as the safety requirements. The attention should be paid also to secondary contamination. While sandblasting is the most commonly applied technique in paint removal, special attention should be paid in order to meet the safety requirements and also to prevent the exposures of workers (cf. exposure to lead or asbestos). Also the cleaning, especially after the paint removal, is important. Especially, if buildings are renovated from industrial to residential use, the clean-up is important in preventing the PCB exposure. Further the risk assessment is to be done by using three types of scenarios: residential, occupational and environmental.

\section{References}

[1] Gjessing, E.T., Steiro, C., Becher, G. and Christy, A. Reduced analytical availability of polychlorinated biphenyls (PCBs) in colored surface water. Chemosphere, 2006, doi:10.1016/j.chemosphere.2006.07.086.

[2] Breivik, K., Sweetman, A., Pacyna, J. M. and Jones, K. C., 2002. Towards a global historical emission inventory for selected PCB congeners - a mass balance approach 1. Global production and consumption. The Science of the Total Environment. Vol. 290, pp. 181-198, 2002.

[3] Jensen, S. Report of new chemical hazard. New Scientist. Vol. 32, p. 612, 1966. 
[4] Hellman, S. Saumausmassojen PCB-yhdisteet elementtitalojen pihamaiden ongelmana. MSc Thesis. Tampereen teknillinen korkeakoulu, Tampere. $104 \mathrm{p}, 2000$.

[5] VNp, 1071/1989. Decision of the Council of State 1071/1989. Government decision on restricting the use of PCBs and PCTs. Ministry of Environment, Finland.

[6] Pentti, M. and Haukijärvi, M. Betonijulkisivujen saumausten suunnittelu ja laadunvarmistus. Tampereen teknillinen korkeakoulu, Talonrakennustekniikka. Publication no 1000, 2. edition. Tampere. 88 p. + app. 2000.

[7] PCB-committee report, 1983. Committee report 1983:47. Government printing center. Helsinki. Finland.

[8] Pyy, V, and Lyly, O. PCB elementtitalojen saumausmassoissa ja pihojen maaperässä [PCB in apartment building sealants and soil]. Summary in English. Helsinki City Environment Centre, Helsinki, Finland, 1998.

[9] Hellman, S. and Puhakka, J. Polychlorinated Biphenyl (PCB) contamination of apartment building and its surroundings by construction block sealants. Geological Survey of Finland, Special Paper Vol. 32, pp. 123-127, 2001.

[10] Priha, E., Hellman, S. and Sorvari, J. PCB contamination from polysulphide sealants in residential areas - exposure and risk assessment. Chemosphere Vol. 59, pp. 537-543, 2005.

[11] Benthe, C., Heinzow, B., Jessen, H., Mohr, S. and Rotard, W. Polychlorinated biphenyls in indoor air due to Thiokol-rubber sealant in office buildings. Chemosphere 25, pp. 1481-1486, 1992. 